\title{
Effect of volcanic tuff on the characteristics of cement mortar
}

\section{(Efeito de tufos vulcânicos nas características da argamassa de concreto)}

\author{
Jehad Al-Zou'by' ${ }^{1}$, Kamel K. Al-Zboon ${ }^{2}$ \\ ${ }^{1,2}$ Al-Huson University College, Al-Balqa' Applied University \\ ${ }^{1,2}$ Environmental Department \\ alzboon@bau.edu.jo
}

\begin{abstract}
This paper examines how Jordanian volcanic tuff aggregates affect the characteristics of cement mortar. Five mortar mixes were prepared by replacing normal aggregate (standard sand) with volcanic tuff aggregate in ratios of $0,25,50,75$, and 100\% (M1 to M5, respectively). Compressive strength, flexural strength, and unit weight were tested at mortar ages of 3, 7, 28, and 56 days. The results revealed improved compressive and flexural strength, which were maximal for the M3 sample. Unit weight decreased as the ratio of volcanic tuff increased. Based on these results, adding Jordanian volcanic tuff in the appropriate ratio will improve these mortar characteristics.
\end{abstract}

Keywords: compression, flexure, Jordan, mortar, volcanic tuff.

\section{Resumo}

Este artigo examina como agregados de tufos vulcânicos jordanianos afetam as características de argamassas de concreto. Cinco misturas de argamassas foram preparadas substituindo o agregado normal (areia padrão) com agregados de tufos vulcânicos nas proporções 0, 25, 50, 75, e 100\% (M1 a M5, respectivamente). Resistência à tração, resistência à flexão, e peso unitário foram testados para tempos de argamassa 3, 7, 28, e 56 dias. Os resultados mostram melhoria nas resistências à tração e à flexão, com valores máximos para a amostra M3. O valor do peso unitário diminuiu com o aumento da proporção de argamassa vulcânica. Portanto, a adição de argamassa vulcânica jordaniana na proporção adequada melhora as características da argamassa.

Palavras-chave: compressão, flexão, Jordânia, argamassa, tufo vulcânico.

\section{INTRODUCTION}

Mortar is a workable paste typically made from a mixture of fine aggregate, a binder such as cement or lime, and water. Mortar becomes hard when it sets, resulting in a rigid aggregate structure. It is used in masonry to bind bricks and stones, to provide an even bed between joints, and to plaster and point exposed masonry surfaces. Mortar in a thin liquid form (grout) is used to fill empty joints in masonry, to stabilize soil, to solidify porous rock, to make cast-in-situ reinforced concrete membranes, and has many other uses [1].

The first zeolite (phillipsite) deposit was discovered in Jordan in 1987, in the Quaternary volcanic tuff of the Jabal Al Aritayn Volcano in northeast Jordan. In 1996, six localities with zeolite deposits were discovered in the volcanic tuff outcrops in northeast Jordan. According to Natural Resources Authority (NRA) estimates, the reserves of volcanic tuff in Jordan exceed two billion tons [2].

The advantages of volcanic tuff include its highly porous structure, high surface area, and low density. It is available in different types, sizes, and colors, and can reduce concrete dead weight. Similar to other pozzolanic material, such as silica fumes and fly ash, substitution with zeolite can improve the strength of concrete via the pozzolanic reaction with $\mathrm{Ca}(\mathrm{OH})_{2}$ [3]. It can prevent the bleeding, segregation, and delamination of fresh concrete, facilitate pumping processes, decrease the permeability of hardened concrete, enhance durability (especially resistance to alkali-aggregate reactions), increase concrete strength, and minimize the cracking in concrete caused by self-shrinkage [4].

Many recent studies have examined the feasibility of using volcanic tuff as lightweight aggregate, building stone, and pozzolans in cements and concretes [5-14]. The US Department of the Interior Bureau of Reclamation studied the physical and chemical properties of several types of light-weight aggregate, including volcanic tuff (scoria and pumice) [14]. The results verified the feasibility of using such aggregates to produce lightweight concrete. They also used scoria and some expanded slags to produce lightweight concrete with intermediate compressive strength, variable workability, and very satisfactory light-weights ranging from 90 to 110 pounds per cubic foot [14]. Authors investigated the properties of volcanic tuff sand and checked its suitability for use in mortar mixes [8]. Their results indicated that volcanic tuff sand increased mortar adhesion, bonding strength, and durability. Authors reported the physical and mechanical properties of yellow volcanic tuff found in Europe [15]. Authors examined how volcanic tuff aggregates affect the unit weight and strength of concrete, and found that unit weight and strength were reduced as 
the percentage of volcanic tuff increased [11]. Authors reported the addition of 9, 14, 15 wt.\% Afyon Volcanic Tuff (AVT) to a standard wall tile body and found that it could be used successfully to produce wall tiles [9]. The alkaline properties, viscosity, water absorption, and compressive strength of specimens are slightly affected by adding AVT. Authors reported the use of volcanic tuff and other materials to form a composite for masonry blocks [16].

Therefore, this study aims to evaluate how raw volcanic tuff affects the characteristics of cement mortar using different ratios of normal to volcanic tuff aggregates, with a constant water to cement ratio.

\section{MATERIALS AND METHODS}

Materials: $12 \mathrm{~m}^{3}$ of raw volcanic (red tuff) was obtained from Jabal Artin, southeastern Jordan. The required quantity was crushed, sieved, and separated into sizes that met the specifications of standard sand (ASTM C778), with sieve numbers $16,20,50,30,40$, and 100 . Normal sand was sieved into similar sizes as the volcanic sample. The specific gravity and absorption of the sand were determined according to ASTM C128. The unit weight was determined in accordance with ASTM C29. The chemical composition of the tuff sand was determined using X-ray diffraction (XRD) and X-ray fluorescence (XRF), and is shown in Tables I and II, respectively. The cement used in this study was ordinary Portland cement type I.

Batching: according to ASTM C109, the proportions of

Table I - Physical properties of volcanic tuff sand.

[Tabela I - Propriedades fisicas da areia do tufo vulcânico.]

\begin{tabular}{ll}
\hline Parameter & \\
\hline Size & $150 \mu \mathrm{m}-1.18 \mathrm{~mm}$ \\
Oven Dry specific gravity & 1.962 \\
Saturated surface dry & 2.226 \\
specific gravity & $2227 \mathrm{~kg} / \mathrm{m}^{3}$ \\
Bulk density & $12.74 \%$ \\
Water absorption ratio by & Rough, hard, and angular \\
weight & surface \\
Surface texture & \\
\hline
\end{tabular}

materials for standard mortar should be 1 part of cement to 2.75 parts of graded standard sand by weight and a watercement ratio of 0.485 for all Portland cements [17]. To investigate how tuff sand affected the mortar characteristics, five mortar batches were prepared in accordance with ASTM C305. A mechanical mixer with a controlled mixing speed and mixing time was used for this purpose. The required standard sand was replaced by similar weights of tuff sand in proportions of $0,25,50,75$, and $100 \%$, as shown in Table III. Both the standard sand and tuff sand were in a saturated surface dry condition.

Molding and curing: molding of specimens to determine their compressive and flexural strength was begun after the completion of batching, in accordance with ASTM C109 and ASTM C348, respectively. Table IV lists the dimensions and numbers of specimens for each batch. All molding requirements (e.g., mold preparation, mortar layers, tamping, mixing speed, and timing) were considered. Immediately upon the completion of molding, the test specimens were placed in a moist room with their upper surfaces exposed. After $24 \mathrm{~h}$, the specimens were cured in a water bath constructed of non-corroding materials at room temperature for periods of $3,7,28$, and 56 days.

Table II - Chemical composition of the volcanic tuff and the standard sand.

[Tabela II - Composição química do tufo vulcânico e da areia padrão.]

\begin{tabular}{ccc}
\hline Parameter & $\begin{array}{c}\text { Volcanic Sample } \\
(\%)\end{array}$ & $\begin{array}{c}\text { Standard } \\
\text { sand (\%) }\end{array}$ \\
\hline $\mathrm{SiO}_{2}$ & 41.699 & 99.5 \\
$\mathrm{CaO}$ & 12.831 & 0.03 \\
$\mathrm{Al}_{2} \mathrm{O}_{3}$ & 10.604 & $0.15-0.30$ \\
$\mathrm{Fe}_{2} \mathrm{O}_{3}$ & 8.87 & $0.015-0.03$ \\
$\mathrm{MgO}$ & 6.249 & 0.005 \\
$\mathrm{TiO}_{2}$ & 2.300 & $0.016-0.04$ \\
$\mathrm{~K}_{2} \mathrm{O}$ & 1.416 & $\mathrm{BDL}$ \\
$\mathrm{Na}_{2} \mathrm{O}$ & 1.057 & $\mathrm{BDL}$ \\
$\mathrm{P}_{2} \mathrm{O}_{5}$ & 0.360 & $\mathrm{BDL}$ \\
$\mathrm{MnO}$ & 0.126 & $\mathrm{BDL}$ \\
\hline BDL. below detectable limit. &
\end{tabular}

Table III - Materials used for different batches.

[Tabela III - Materiais usados para diferentes lotes.]

\begin{tabular}{ccccccc}
\hline $\begin{array}{c}\text { Batch } \\
\text { designation }\end{array}$ & Tuff percent & Tuff wt. (g) & Standard sand (g) & Water (g) & Cement (g) & Total wt. (g) \\
\hline M1 & $0 \%$ & 0.00 & 2475 & 436.5 & 900.00 & 3811.5 \\
M2 & $25 \%$ & 618.75 & 1856.25 & 436.5 & 900.00 & 3811.5 \\
M3 & $50 \%$ & 1237.5 & 1237.5 & 436.5 & 900.00 & 3811.5 \\
M4 & $75 \%$ & 1856.25 & 618.75 & 436.5 & 900.00 & 3811.5 \\
M5 & $100 \%$ & 2475 & 0.00 & 436.5 & 900.00 & 3811.5 \\
\hline
\end{tabular}


Mechanical properties: after the curing period the specimens were removed from the baths, wiped to give a dry surface, and any loose sand, grains, or incrustations were cleaned from the faces so that they would not prevent contact with the bearing blocks of the testing machine [17]. All samples were sent to the laboratory and tested within 1 h. For the compression strength test, a constant loading was applied on the specimen in the range of 200-400 lbs/s (900$1800 \mathrm{~N} / \mathrm{s}$ ). Compression strength was calculated as follows:

Table IV - Dimensions and numbers of specimens per each test.

[Tabela IV - Dimensões e número de espécimes em cada teste.]

\begin{tabular}{ccc}
\hline Test & $\begin{array}{c}\text { Specimen } \\
\text { dimensions }\end{array}$ & $\begin{array}{c}\text { Number of } \\
\text { specimens } \\
\text { per batch }\end{array}$ \\
\hline $\begin{array}{c}\text { Physical } \\
\text { characteristics } \\
\text { Chemical } \\
\text { characteristics } \\
\begin{array}{c}\text { Compressive } \\
\text { strength }\end{array}\end{array}$ & $30 \mathrm{~kg}$ & $3^{*}$ \\
$\begin{array}{c}\text { Flexural } \\
\text { strength }\end{array}$ & $30 \mathrm{~kg}$ mm cubes & $3^{*}$ \\
$*$ total, $* *$ per batch & prisms $160 \mathrm{~mm}^{3}$ & $24^{* *}$ \\
$F_{m}=P / A$ & &
\end{tabular}

where $F_{m}$ is the compressive strength in $\mathrm{MPa}, P$ is total maximum load in $\mathrm{N}$, and $A$ is the area of loaded surface in $\mathrm{mm}^{2}$.

For the flexural strength test, a center-point loading machine was used; its bearing edge was adjusted so that it was at exactly right angles to the length of the prism and parallel to its top face as placed, with the center of the bearing edge directly above the center line of the prism and at the center of the span length. The load was applied at a rate of $600-625 \mathrm{lb} / \mathrm{min}(2640-2750 \mathrm{~N} / \mathrm{min})$, which produced failure in an average time of $50 \mathrm{~s}$. The flexural strength, Fr, in MPa can be calculated as:

$$
F_{r}=0.0028 P
$$

where $P$ is the total maximum load in N.

\section{RESULTS AND DISCUSSION}

Physical and chemical characteristics: the physical properties of the volcanic tuff sand were investigated in accordance with ASTM C128. Compared with standard sand, the volcanic tuff had a lighter specific gravity, which proved its useful for producing lightweight concrete. It absorbed more water $(12.7 \%)$ than standard sand $(0.65 \%)$, which was attributed to the high surface area and porosity. It has been reported that the water absorption of Jordanian tuff ranged from $11.1 \%$ (grey tuff) to $25.1 \%$ (brown tuff) [18]. Chemically, the volcanic tuff consisted mainly of silica, lime, and other oxides, while $99.5 \%$ of the standard sand was $\mathrm{SiO}_{2}$. Similar results have been reported by other researchers. The physical and mechanical properties of tuff widely vary according to the quarry location and type of rocks [19].

Density of cement mortar: Figs. 1 and 2 show the density of each batch of cubes and prism specimens, respectively. The average density ranged from $2056-2199 \mathrm{~kg} / \mathrm{m}^{3}$ for cube samples and from $2097-2191 \mathrm{~kg} / \mathrm{m}^{3}$ for prism samples. M1 (100\% sand) had the highest density, while M5 (100\% volcanic) had the lowest; this was caused by the lower specific gravity of the volcanic tuff in comparison with standard sand. The maximum reduction in density was $5.5 \%$, in M5 cube samples at 7 days. Sand or volcanic tuft constituted only $65 \%$ of the mix volume, while cement and water contributed $35 \%$. The water and cement contents were kept the same in all batches, which explains the slight reduction in the density of the volcanic specimens. It has been found that the unit weight decreased with increasing zeolite content in concrete [20]. It has been found that the density of concrete made of volcanic tuff materials was $2059 \mathrm{~kg} / \mathrm{m}^{3}$ versus $2398 \mathrm{~kg} / \mathrm{m}^{3}$ for normal concrete [21]. Incorporating volcanic ash (VA) in concrete mixes has a similar effect where the density decreased from $2390 \mathrm{~kg} /$ $\mathrm{m}^{3}$ in control samples ( $\left.0 \% \mathrm{VA}\right)$ to $2285 \mathrm{~kg} / \mathrm{m}^{3}$ at $30 \% \mathrm{VA}$, representing a decrease of about $4.4 \%$ [22].

Compressive strength: Following ASTM C109 guidelines, $50-\mathrm{mm}$ cubes of cement mortar were tested after curing periods of $3,7,28$, and 56 days, as shown in Table V. The M3 specimens had higher strength than the M2, M4, and M5 specimens and close to M1 value. Based on the average strengths for all tests and ages, the batch was ranked in the order M3 $>$ M1 $>$ M4 $>$ M2 $>$ M5 (Figs. 3-6).

This means that replacing standard sand with $50 \%$ volcanic tuff slightly improved $(<1.6 \%)$ the compression strength of cement mortar. This result was expected, because the physical characteristics of volcanic tuff sand (i.e., its rough, angular surface texture) increase the bond between

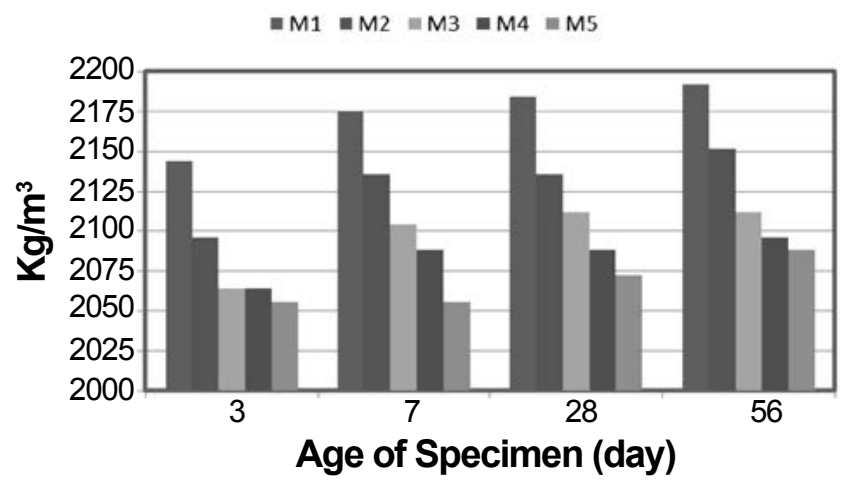

Figure 1: Average unit weight of cube specimens.

[Figura 1: Peso unitário médio das amostras cúbicas.] 


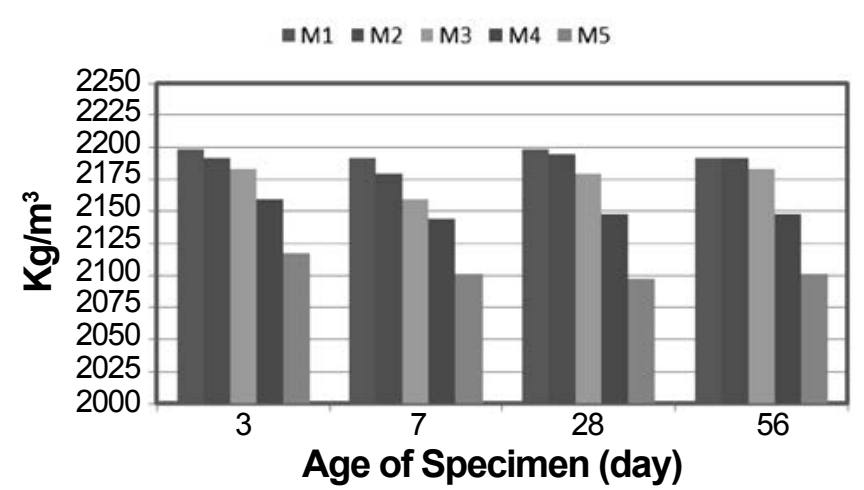

Figure 2: Average unit weight of prism specimens.

[Figura 2: Peso unitário médio das amostras prismáticas.]

Table V - Decrease/increase percentage of the compression strength in comparison with the control batch.

[Tabela V - Aumento e diminuição da resistência a compressão em comparação com o lote de controle.]

\begin{tabular}{cccccc}
\hline $\begin{array}{c}\text { Batch } \\
\text { designation }\end{array}$ & $\begin{array}{c}\text { Tuff } \\
\text { percent }\end{array}$ & 3-days & 7-days & 28-days & 56-days \\
\hline M1 & 0 & 0 & 0 & 0 & 0 \\
M2 & 25 & -19.4 & -15.7 & -19.6 & -15.2 \\
M3 & 50 & 0.2 & 1.6 & 0.7 & -0.9 \\
M4 & 75 & -11.8 & -2.1 & -16.1 & -12.7 \\
M5 & 100 & -34.3 & -17.7 & -26.1 & -23.5 \\
\hline
\end{tabular}

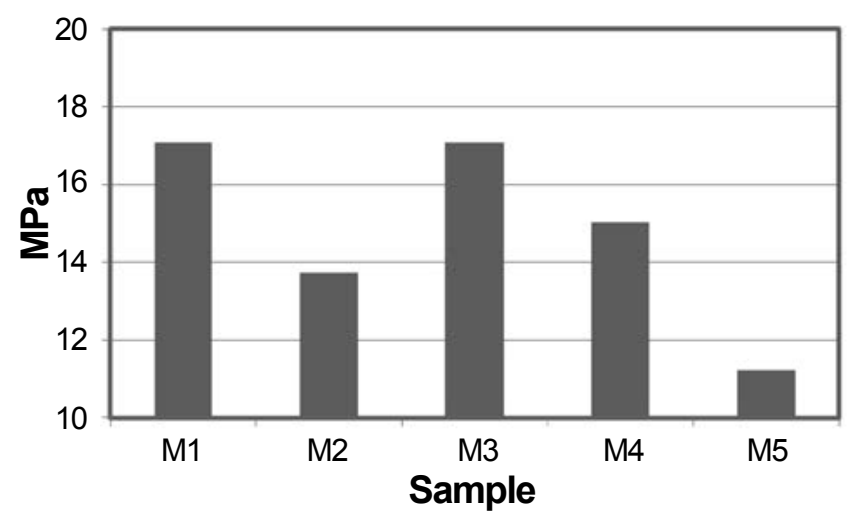

Figure 3: Compression strength of mortar at 3 days age.

[Figura 3: Resistência à compressão da argamassa envelhecida durante 3 dias.]

the aggregate and cement paste, which in turn increase the mortar strength. Conversely, the large specific surface area of volcanic tuff sand, compared with standard sand, requires more cement paste for coating, which is why M4 and M5 had lower compressive and flexural strengths than M3. Additionally, when added in higher ratios, volcanic tuff materials have a high absorption ratio, which decreases the $\mathrm{W} / \mathrm{C}$ ratio needed for reaction, affecting the strength of the mixes. It was found that adding volcanic tuff to the concrete mix in a ratio of $20 \%$ increased compression strength by $3.8-19.9 \%$, depending on the strength of the

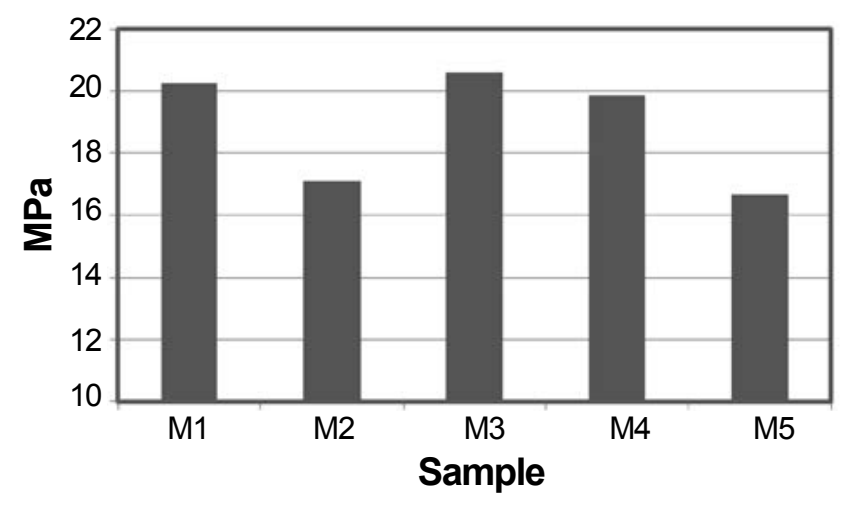

Figure 4: Compression strength of mortar at 7 days age.

[Figura 4: Resistência à compressão da argamassa envelhecida durante 7 dias.]

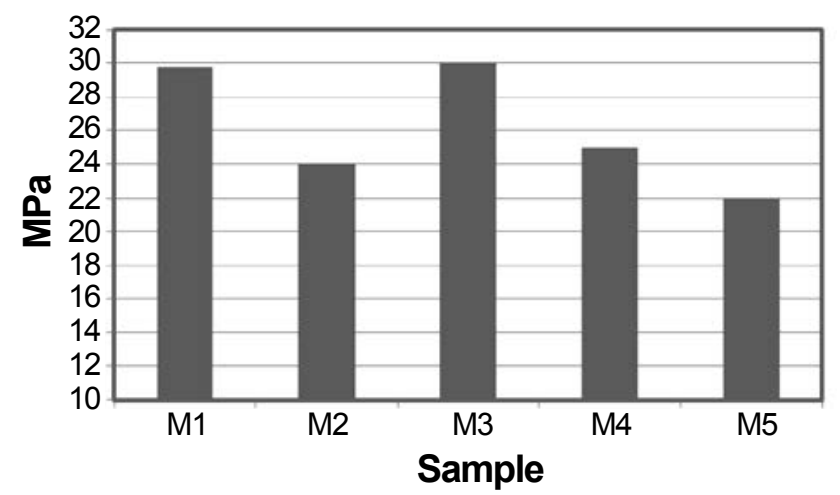

Figure 5: Compression strength of mortar at 28 days age.

[Figura 5: Resistência à compressão da argamassa envelhecida durante 28 dias.]

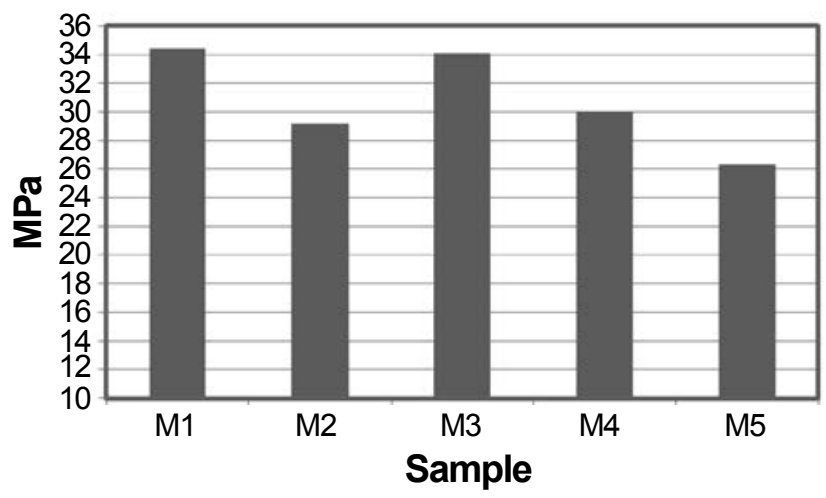

Figure 6: Compression strength of mortar at 56 days age.

[Figura 6: Resistência à compressão da argamassa envelhecida durante 56 dias.]

concrete and the type of volcanic material [18]. It was found no significant difference in the compression strength of lightweight concrete samples including volcanic tuff versus normal concrete samples [21]. Authors used zeolite in concrete in ratios of 5,10 , and $15 \%$, and found that compressive strength increased with increasing zeolite content [20]. It was found the opposite, reporting that the Schmidt hardness, compressive strength, and flexural strength all decreased with increasing zeolite content in the concrete [4]. It was reported that $30 \%$ volcanic tuff in 
Table VI - Decrease/increase of the flexural strength in comparison with the control batches.

[Tabela VI - Diminuição e aumento da resistência à flexão em comparação com lote de controle.]

\begin{tabular}{cccccc}
\hline $\begin{array}{c}\text { Batch } \\
\text { designation }\end{array}$ & $\begin{array}{c}\text { Tuff } \\
\text { percent }\end{array}$ & 3-days & 7-days & 28-days & 56-days \\
\hline M1 & 0 & 0 & 0 & 0 & 0 \\
M2 & 25 & -2.5 & -4.3 & 5.7 & 6.1 \\
M3 & 50 & 2.0 & 1.5 & 12.5 & 15.3 \\
M4 & 75 & -16.0 & -13.2 & 3.7 & 4.5 \\
M5 & 100 & -31.2 & -21.7 & 2.3 & 2.0 \\
\hline
\end{tabular}

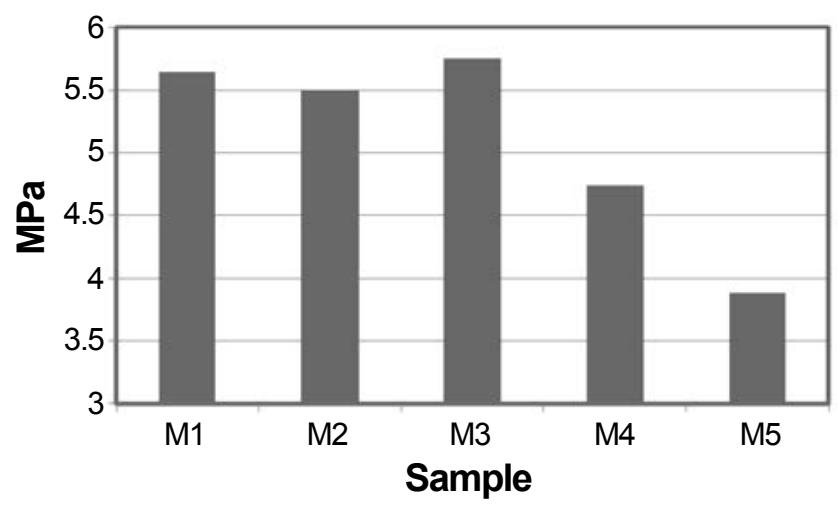

Figure 7: Flexural strength of mortar at 3 days age.

[Figura 7: Resistência à flexão da argamassa envelhecida durante 3 dias.]

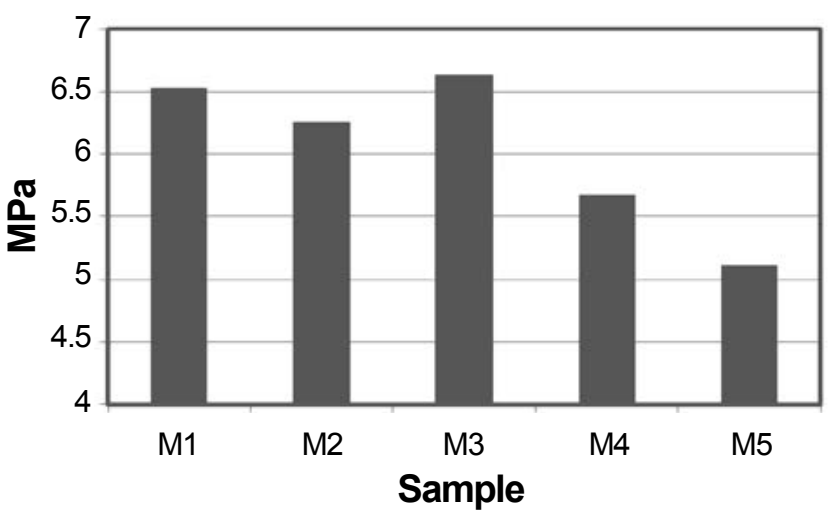

Figure 8: Flexural strength of mortar at 7 days age.

[Figura 8: Resistência à flexão da argamassa envelhecida durante 7 dias.]

concrete reduced compression strength by $28 \%$ [22]. Authors reported that the compression strength of normal concrete (300 $\mathrm{kg} / \mathrm{cm}^{2}$ ) made with limestone at 28 days was greater than that made with volcanic rock, by approximately $0.2,5$, and $14 \%$, for maximum aggregate sizes of 10,20 , and $40 \mathrm{~mm}$, respectively [23]. High-strength concrete $\left(800 \mathrm{~kg} / \mathrm{cm}^{2}\right)$ made with limestone had higher compression strength than concrete made with volcanic rock, by approximately 4,6 , and $7 \%$ for the respective sizes.

Flexural strength: the flexural strength of $40 \times 40 \times 160$ $\mathrm{mm}^{3}$ mortar prisms was tested after curing periods of 3,7 ,

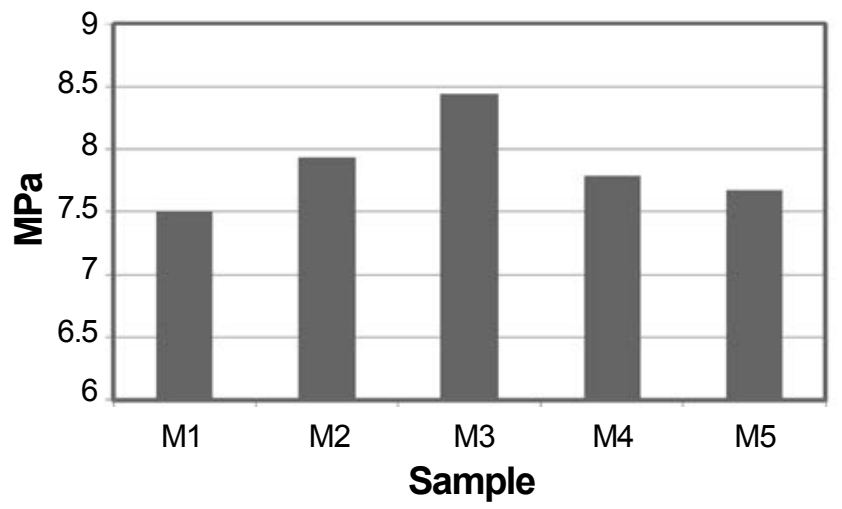

Figure 9: Flexural strength of mortar at 28 days age.

[Figura 9: Resistência à flexão da argamassa envelhecida durante 28 dias.]

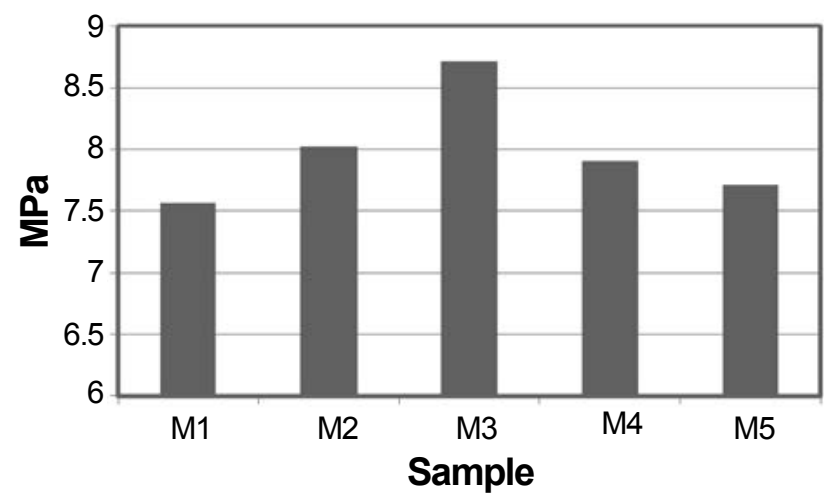

Figure 10: Flexural strength of mortar at 56 days age.

[Figura 10: Resistência à flexão da argamassa envelhecida durante 56 dias.]

28, and 56 days. After 28 days, M2 and M3 samples had flexural strength of 7.93 and $8.44 \mathrm{MPa}$, respectively, while M1 samples had a $7.5 \mathrm{MPa}$ (Fig. 9). At 28 and 56 days, all batches had higher strength than M1 samples, as shown in Tables V and VI. At all ages, M3 samples had the highest flexural strength, verifying the beneficial effect of using volcanic tuff in cement mortar in a 50\% ratio (Figs. 7-10).

The M3 mortar had more rough and angular particles than M2 samples, and a smaller surface area than M4 and M5 samples, which resulted in higher strength. A comparison between M3 and M1 mortar (the control mortar) would depend on the same issues of surface texture and surface area, along with the fact that moderate- or low-strength aggregates can be valuable in preserving the integrity of concrete, which is the case with volcanic tuff sand [24]. Natural sand has a smaller surface area, so a smaller amount of cement is sufficient to coat the sand, accelerating the hydration process and resulting in a rapid initial increase in strength. This explains the higher flexural strength of M1 at 3 and 7 days.

It was reported normal concrete $\left(300 \mathrm{~kg} / \mathrm{cm}^{2}\right)$ made with limestone at 28 days had a lower flexural strength than concrete made with volcanic rock, by approximately 6,4 , and $2 \%$, for a maximum aggregate size of 10,20 , and $40 \mathrm{~mm}$, respectively [23]. 


\section{CONCLUSIONS}

This study evaluated how volcanic tuff sand affected compressive strength, flexural strength, and the unit weight of mortar. Five mortar batches were produced, using various weight ratios of normal sand to volcanic tuff sand. Based on the results, we concluded that Jordanian volcanic tuff can be used successfully as construction material. Moreover, the results revealed that the appropriate ratio of blended aggregate, i.e., 50\% Jordanian volcanic tuff (from Jabal Artin) can improve mortar characteristics and reduce the unit weight of mortar to some extent.

\section{ACKNOWLEDGEMENTS}

This research would not have been possible without financial support from the Scientific Research Support Fund (SRF) under the project "Utilization of Jordanian volcanic tuff in different engineering applications". We would like to place on record our sincere appreciation for the funding provided by SRF.

\section{REFERENCES}

[1] Z. Y. Zhang, M. Jin, S. C. See, M. O. W. Richardson, E. Rirsch, D. Lambert, et al. "Investigation into nanoclay enhanced coatings for brick moisture reduction and salt formation prevention", in: Protection of historical buildings - PROHITECH Conf., Rome, Italy (2009).

[2] NRA, National Resources Authority of Jordan, Report: Zeolatic Tuff www.NRA.gov. (2006).

[3] F. Negis, "Zeolite based composites in energy storage", M.Sc. Diss., Izmir Institute of Technology, Turkey (1999).

[4] K. Semsettin, "The effect of zeolite amount on the physical and mechanical properties of concrete", Int. J. Phys. Sci. 6, 13 (2011) 3041-3046.

[5] Y. Abali, S. U. Bayca, S. Targan, "Evaluation of blends tincal waste, volcanic tuff, bentonite and fly ash for use as a cement admixture", J. Hazard. Mater. 131, 1-3 (2006) 12630 .

[6] N. Augenti, F. Parisi, "Constitutive models for tuff masonry under uniaxial compression", J. Mater. Civ. Eng. 22, 11 (2010) 1102-1111.

[7] G. Faella, G. Manfredi, R. Realfonzo, "Cyclic Behaviour of Tuff Masonry Walls Under Horizontal Loading”, in: Proc. $6^{\text {th }}$ Can. Masonry Symp., Canada (1992) 317-328.

[8] A. Kan, R. Gul, "Properties of Volcanic Tuff Sands as a New Material for Masonry Mortar", Int. J. Nat. Eng. Sci. 2 (2008) 69-74; H. Kaplan, H. Binici, Cem. Concr. World 1 (1996) 23-30.

[9] T. Kavasa, A. Evcin, "Use of Afyon region (Turkey) volcanic tuffs in wall tile production", J. Ind. Ceram. 25, 1 (2005) 17-19.

[10] A. Kılic, C. D. Ati, A. Teymen, O. Karahan, Ari
Kamuran, "The effects of scoria and pumice aggregates on the strengths and unit weights of lightweight concrete", Sci. Res. Essays 4, 10 (2009) 961-965.

[11] A. Kilic, C. D. Atis, E. Yasar, F. Ozcan, "High-strength lightweight concrete made with scoria aggregate containing mineral admixtures", Cem. Concr. Res. 33, 10 (2009) 15951599.

[12] M. M. Smadi, E. Migdady, "Properties of High Strength Tuff Lightweight Aggregate Concrete", Cem. Concr. Comp. 13, 2 (1991) 129-135.

[13] A. G. Turkmenoglu, A. Tankut, "Use of tuffs from central Turkey as admixture in pozzolanic cements assessment of their petrographical properties", Cem. Concr. Res. 32, 4 (2002) 629-637.

[14] USBR, US Bureau of Reclamation, "Concrete manual. A Manual for the Control of Concrete Construction", $7^{\text {th }}$ Ed., United States Printing Office, Denver, Colorado, USA (1963).

[15] G. Marcari, G. Manfredi, A. Prota, M. Pecce, "In-plane shear performance of masonry panels strengthened with FRP”, Composites Part B 38, 7-8 (2007) 887-901.

[16] A. Hartley, G. Mullins, R. Sen, "Repair of concrete masonry block wall using carbon fiber", in:Proc. Adv. Composite Mater. Bridges Struct., Montreal, Quebec, Can. Soc. Civil Eng. (CSCE) (1996) 795-802.

[17] WSDOT, Washington State Department of Transportation, "Compressive Strength of Hydraulic Cement Mortars (Using 2-in. or (50-mm) Cube Specimens", http:// www.wsdot.wa.gov/publications/manuals/fulltext/M46-01/ t106.pdf (2010).

[18] A. Yasin, T. A. Mohammed, R. H. Hassan, I. S. Eid, "Effect of volcanic tuff on the concrete compressive strength", Contemp. Eng. Sci. 5, 6 (2012) 295-306.

[19] A. Evangelista, A. Pellegrino, "Caratteristiche geotecniche di alcunerocce tenere italiane", Atti del Terzo Ciclo Conf. Meccanica Ingegneria delle Rocce MIR90, Torino, Italy (1990).

[20] C. Basyigit, "The effect of zeolit rate on the thermomechanical properties of concrete", Int. J. Phys. Sci. 5, 7 (2010) 968-971.

[21] Abu-Baker Mohammad, "Comparison the compression strength of the light weight concrete made of volcanic tuff with normal concrete", $2^{\text {nd }}$ Int. Eng. Conf., Aden, Yemen, www.adenuniv.net/uploads/conf/Engg\%202/ vol\%201/22. $\operatorname{pdf}(2009)$.

[22] B. J. Olawuyi, K. O. Olusola, "Compressive Strength of Volcanic Ash/Ordinary Portland Cement Laterized Concrete", Civ. Eng. Dim. 12, 1 (2010) 23-28.

[23] P. Piyachon "Properties of Concrete using Coarse Aggregate from Volcanic Rock", M.Sc. Thesis, Kasetsart Univ. (2004).

[24] A. M. Neville, J. J. Brooks, "Concrete Technology", Longman Sci. Tech. Publ. (1987) Chapt. 12 and 13.

(Rec. 04/07/2013, Ac. 17/11/2013) 